\title{
Analysis of the effect on inflation, interest rate, dow jones Islamic Malaysia Index and profitability on stock prices as selected as Indonesia Sharia Stock Index Sofyan Halim
}

\author{
Universitas Mercu Buana Jakarta, Indonesia \\ email: sofyan.halm@mercubuana.ac.id
}

\begin{abstract}
Purpose - The purpose of this study was to analyze what influences the change in the ISSI price index. The analysis was based on the phenomena and hypotheses that occur in the capital market by examining whether there is an influence of inflation rates, interest rates, and the Dow Jones Islamic Malaysia Index as external factors, as well as profitability such as Return on Assets and Earning per Share as internal factors that have an influence on changes and fluctuations in the Sharia Stock Index.
\end{abstract}

Method - The population in this study are all stocks that are encoded in the Indonesia Sharia Stock Index (ISSI) listed on the Indonesia Stock Exchange. Based on the Sharia Stock Exchange and the number of shares indexed by ISSI was 408 shares which shares were classified into 11 types of business. The study was conducted by analyzing multiple regression with t-test, significance test, F test, and classical assumption test.

Result - Based on the research results of bank interest rates and the Dow Jones Islamic Malaysia Index which affect stock prices indexed as Indonesia Sharia Stock, the two variables are the external influence of the issuers of the shares. And the majority of these stock prices are strongly influenced by variable factors not examined.

Implication - This research indicates that the factors that influence stock prices indexed as Islamic stocks in Indonesia, the analysis of the coefficient of determination is not significant at $0.6 \%$, to find out other factors, other variables are needed for further research.

Originality - This research is a continuation of previous research but uses different variables from previous researches, where the dependent variable is stock prices indexed as Indonesian Islamic stocks and the independent variable is the inflation rate, interest rate, and the Malaysian Islamic Dow Jones Indexas factors.

Keywords: Indonesia Sharia Stock Index; inflation; interest rate; dow jones sharia index; profitability 
Sofyan Halim

\section{Introduction}

When investing, investors will consider various factors that will affect it. In placing the investment fund, they will consider to invest in the best places. JIAFR | 260 Then investors will pay attention to the internal and external factors of the company or place of the investment. Investing in the capital market is the investors' choice among various investment sites by owning shares of public companies and more specifically on public shares categorized as shares based on sharia. Besides estimating maximum profits, the investor takes risks into consideration-the risks that will arise from the investment itself. Investment risks in shares include the estimated potential loss from the difference in price at the sale of shares which is lower than the price at the time of purchase. The company whose shares were purchased, decreased company profits or even losses so that the potential did not receive dividends, or even the company bought shares went bankrupt and liquidated to cause the price of the shares to go down and not to register so that the shares cannot be sold and the value is reduced significantly even zero. Therefore, when investing an investor will consider the gains and risks that may occur during investing.

In addition to the risks that may occur, of course, there are potential gains or benefits from investing and trading shares including the shareholder having the right to attend the General Meeting of Shareholders and being recognized as the owner of the company, has the right to receive dividends on each sheet of company stock ownership, and get a gain from the margin in selling price of shares which is higher than the purchase price of shares owned. Based on the considerations of the risks and the potential benefits obtained, it can be analyzed that each potential profit to be obtained there is a risk that might occur, then usually the higher the risk of buying and selling shares, the higher the potential profit to be obtained, conversely, the risk is low then the profit potential is also low. The risks mentioned above are some factors causing the rise and fall of share prices, especially public shares including external causes such as inflation, fluctuations in foreign exchange rates, bank interest rates and the influence of global markets; while the internal influences of public companies in the form of company performance 
Analysis of the effects of inflation, interest rate, dow jones Islamic Malaysia Index ...

itself are such as the problem of profitability, liquidity, the profitability of the company. According to Zarah Puspitaningtyas (2015) in her book entitled Prediction of Stock Investment Risk, predicting the level of risk in investment is needed to minimize losses or optimize returns by taking advantage of movement trends, based on the concept of portfolio diversification and stock risk. Investment risk is categorized into two types of risk, which include systematic risk or market risk and unsystematic risk.

The influence of global and macroeconomic conditions can be significant to the movement of stock prices on the stock exchange. As a result, these stock prices which are categorized as lower layer stocks that are not favorites for investors to glance at can suddenly rise. Otherwise, blue-chip stocks can experience a decline. Then, before taking a decision, investors need to analyze the conditions as the factors that affect the price movements of these shares.

Among the stocks listed on the Indonesia Stock Exchange, there are shares that are categorized as shares whose business is based on sharia which meets the criteria as a company whose business operations are in accordance with sharia rules and muamalah fiqh. The growth of sharia-based financial instruments such as sharia banking, sharia financing, sharia insurance, bonds, and sharia stocks tend to experience an increasing trend from time to time. Since 2000, the Sharia Index has been launched on the Jakarta Stock Exchange. Since then the development of the Sharia Capital Market has grown, so that until June 2019 there were 408 issuers whose shares were categorized as sharia shares with various types of businesses such as mining, agribusiness, various basic and chemical industries, various industries, financial services, the consumer goods industry, property, real estate and building construction, utility infrastructure and transportation, service trade and investment, and others (Halim, 2020).

Based on the Indonesia Stock Exchange Announcement No. Peng00311/BEI.PQP/06-2019 on June 25, 2019 concerning Changes in Stock Composition in Calculating the Indonesia Sharia Stock Index (ISSI), up to the period of June 26, 2019, there were 408 issuers whose shares were 
Sofyan Halim

categorized and indexed as sharia shares and classified into 11 business sectors with as presented in table 1.

Researches on the Islamic Capital Market in Indonesia have been widely JIAFR | 262 carried out. Darwis Harahap (2016) analyzed factors affecting the Jakarta Islamic Index (JII) stock prices and concluded that the results of the sales movement significantly and positively influence JII shares, book value of JII assets significantly influence the price of the listed company's stock, the movement of the debt ratio of the listed company significantly but negatively affects the company's stock price, the movement of interest rates significantly but negatively affects the stock price of JII, the movement of foreign exchange rates did not significantly affect JII stock prices, and the movement of stock prices in the previous period significantly and positively affected JII stock prices.

Irfan Syauqi Beik \& Sri Wulan Fatmawati (2014) conducted a study on the Effect of the International Sharia Stock Price Index and the Vupdateabke Macroeconomics on the Jakarta Islamic Index (JII), with the results of the VECM analysis showed that in the short term, only DJIJP and IPI significantly influenced JII. Whereas in the long run, DJIEU, DJIMY, and IPI had a significant positive relationship to JII. The DJIJP, IMUS, M2, and SBIS have a significant negative relationship to JII. Meanwhile, the CPI, BI Rate, and ER did not have a significant relationship with JII. Next, the IRF results showed that JII experienced fluctuations in responding to shocks that occur against all macroeconomic variables and observed international sharia stock markets, before then achieving stability. The requirement to achieve this stable condition varied between these variables. JII achieved the fastest stability when responding to shocks to the money supply. Third, the results of the FEVD analysis showed that each variable gave a different contribution to the diversity of JII. At the end of the observation period, CPI was the variable that had the biggest contribution, while M2 was the variable that had the smallest contribution. 
Analysis of the effects of inflation, interest rate, dow jones Islamic Malaysia Index ...

Table 1. The List of Indonesia Sharia Stock Index

\begin{tabular}{clc}
\hline No & \multicolumn{1}{c}{ Issuer of Business Type Categories/Sectors } & $\begin{array}{c}\text { Number of } \\
\text { Issuer }\end{array}$ \\
\hline 1 & Agriculture Business & 10 \\
2 & Basic of industrial and chemical business & 53 \\
3 & Mining Business & 35 \\
4 & Various industries & 29 \\
5 & Consumers Goods Industries & 39 \\
6 & Property, Real Estate and Building Construction Business & 56 \\
7 & Infrastructure, Utilities and Transportation Business & 63 \\
8 & Financial Business & 4 \\
9 & Trading, Services and Investment Business & 109 \\
10 & Publicly listed companies & 3 \\
11 & Unlisted Companies & 7 \\
\hline
\end{tabular}

JIAFR | 263

Ayu Utami and Leo Herlambang (2016) examined the Effect of Macroeconomic Variables on the Jakarta Islamic Index (JII) for the period of January 2010 to November 2015, and concluded that the inflation rate partially and insignificantly influenced the JII, interest rates had a partially significant negative effect on the JII, the exchange rate had a partially significant effect on the JII, and simultaneously, the inflation rate, interest rates, and exchange rate affect significantly to stock price movements on the JII.

Retno Fuji Oktaviani (2017) examined the International Islamic Stock Price Index of the Jakarta Islamic Index and concluded that the Dow Jones Islamic Europe Index did not significantly influence the Jakarta Islamic Index; The Dow Jones USA Index had a negative and significant effect on the Jakarta Islamic Index; The Dow Jones Japan Index had no significant effect on the Jakarta Islamic Index, and the Dow Jones Islamic Malaysia Index had a positive and significant effect on the Jakarta Islamic Index.

Based on the background described above and the results of previous studies, several previous studies made the Jakarta Islamic Index the dependent variable object (variable $\mathrm{Y}$ ) and the object of the independent variables (variable $\mathrm{X}$ ) include income, asset book value, debt ratio, interest 
Sofyan Halim

rate (BI Rate), Foreign Exchange Rates, International Islamic Stock Index, CPI or Inflation Rate, and ER. So in this study, researchers conducted an analysis that is different from the previous researches. What distinguishes this research is the object under study, that is the price of public shares listed on the Indonesia Stock Exchange which is categorized as the Indonesia Sharia Stock Index as the dependent variable (variable Y) and the independent variables consist of external factors like inflation rate, interest rate (BI Rate), and the Dow Jones Islamic Malaysia Index, as well as the company's internal factors by analyzing profitability which includes the company's Net Profit Margin, Return on Investment and Earning Per Share, with a research period from the first quarter of 2015 to the third quarter of 2019.

Based in the description and data in the background above, the aim of this study was to analyze what influences the change in the ISSI price index. The analysis was based on the phenomena and hypotheses that occur in the capital market by examining whether there is an influence of inflation rates, interest rates, and the Dow Jones Islamic Malaysia Index as external factors, as well as profitability such as Return on Assets and Earning per Share as internal factors that have an influence on changes and fluctuations in the Sharia Stock Index.

\section{Literature Review}

\section{Sharia Capital Market}

Law Number 8 of 1995 on Capital Market defined Capital Market as activities related to public offering and trading of securities, Public Companies related to securities issued, and institutions and professions related to securities. It can be interpreted that the Capital Market is run following the principles of sharia, in this case, Islamic sharia-based on the sources of the law of the Qur'an and the Hadith of the Prophet Muhammad SAW. Based on the two sources of law, the scholars agree to do interpretation that both are sources of muamalah fiqh which regulates human relations in conducting trade and trade transactions. In principle, based on the science of muamalah fiqh, it is stated that all forms of mualamalah may be carried out unless there 
is an argument that prohibits and forbids the muamalah. Furthermore, as the jurisprudence of muamalah fiqh law in Indonesia, majority of the scholars agreed to issue a fatwa through the National Sharia Council of the Indonesia Ulema Council. The fatwas become a matter of principle to be carried out by Islamic Financial Institutions, including those principles in the Market Market system (Fitriana, Yulianto \& Solikhah, 2019).

\section{Indonesia Sharia Stock Index}

The Indonesia Sharia Stock Index (ISSI) is a composite index of sharia stocks listed on the IDX and began launching on May 12, 2011. ISSI is an indicator of the performance of the Indonesia sharia stock market. The ISSI constituents are all shares categorized as sharia shares listed on the Stock Exchange Indonesia (IDX) and entered into the List of Sharia Securities issued by the Financial Services Authority. Thus it can be noted that the IDX does not select sharia shares that enter ISSI. The ISSI constituency is reselected twice a year, every May and November, following the DES review schedule. Therefore, in every selection period, there are always sharia shares that go out or enter into ISSI constituents. The ISSI calculation method follows another BEI stock index calculation method, which is the weighted average of market capitalization using December 2007 as the base year for ISSI calculation.

\section{Inflation}

According to Tandelilin, inflation is a tendency for an increase in prices of products as a whole. High inflation reduces the level of real income that investors get from investments. Conversely, if the inflation rate of a country decreases, it is a positive signal for investors along with the decrease in the risk of purchasing power of money and the risk of decreasing real income.

Inflation is generally interpreted as a continuous increase in prices for goods and services. If the price of goods and services in a country increases, inflation increases. Then the increase in prices of goods and services causes a 
Sofyan Halim

decrease in the value of money. So inflation can also be interpreted as a decrease in the value of money against the value of goods and services.

According to Mankiw (2014), inflation is an increase in the average price JIAFR | 266 level, and prices are the rate at which money is exchanged for goods or services. Increases in all price levels are sometimes continuous and prolonged. Inflation is a monetary phenomenon that occurs everywhere. An increase in the price of one or two items alone cannot be called inflation unless it increases (or causes an increase) in other goods.

The Consumer Price Index (CPI) is an indicator that is often used to measure inflation. The CPI is used to calculate the average change in prices of a package of goods and services consumed by households in a certain period of time. Changes in the CPI from time to time reflect the level of increase (inflation) or the rate of decline (deflation) of goods and services. The determination of goods and services in the CPI basket is carried out on the basis of the Cost of Living Survey conducted by Central Bureau of Statistics. Inflation can have an impact on the economy of a country including being able to encourage redistribution of income in society and can cause a decrease in economic efficiency. It happens because inflation directs productive investment resources to unproductive investment, so that it will reduce productive economic capacity. Inflation also causes changes in output and employment opportunities because by motivating companies to produce more or less than they can do, at the same time it also motivates people to work more or less than what has been done so far. Inflation can also create an unstable environment for economic decisions. If unanticipated inflation occurs on an ongoing basis, the level of risk associated with investment in the economy will increase. As a result of the rise in the impact of uncertainty, it can make investors hesitate to invest and make long-term commitments. As investment levels fall, the prospect of long-term economic growth shrinks.

\section{Bank Indonesia Interest Rates (BI Rate)}

The level of profit or value provided to the owner of the fund for the use of investment funds from the owner of the fund is based on the calculation of 
Analysis of the effects of inflation, interest rate, dow jones Islamic Malaysia Index ...

economic value during the agreed period and is referred to as the interest rate. In general, the interest rate used in banks is determined and regulated by the government and its function as a tool control of a country's economy. As in investing their funds investors expect a return on the investment, they will see and analysis the interest rates that apply in a country so that these interest rates become very important and become a reference for them in calculating the funds to be invested.

\section{Interest Rates}

Interest rates according to several sources are: According to Boediono (2014), interest rates are the price of the use of investment funds (loanable funds). The interest rate is one indicator in determining whether someone will invest or save. According to Sunariyah (2013), the interest rate is the price of the loan. Interest rates are expressed as a percentage of the principal per unit time. Interest is a measure of the price of resources used by debtors to be paid to creditors. According to Mishkin (2008), the interest rate is the cost of the loan or the price paid for the loan fund (usually expressed as a percentage per year). According to Judisseno (2002), interest rates are income earned by people who give excess money or surplus spending units to be used temporarily by people who need and use the money to cover their deficits or deficit spending units. According to Brigham (2006), interest rates are the price that must be paid on loan capital, and dividends and capital gains that are the result of equity capital.

Determination of interest rates in a country is usually determined by the Central Bank. In Indonesia, based on Law No. 23 of 1999 concerning Bank Indonesia, the determination of interest rates is regulated by Bank Indonesia so that the specified interest rates are referred to as the BI rate. This BI rate is announced by Bank Indonesia periodically for a certain period and serves as a signal or stance for monetary and economic policies in Indonesia. 
Sofyan Halim

\section{Interest Rate Function}

Based on explanation above, interest rates mean to provide a profit from some funds that are invested or used or lent to other parties based on economic value and the calculation of time during the period of the funds utilized by the user or manager or borrower. The level of profit is determined by the interest rates that are applied. Thus the function of interest rates in the economy according to Sunariah can be explained as follows: As an attraction for investors to invest their funds. The interest rate can be used as a control tool for the government over direct funds or investments in economic sectors. Interest rates can be used as monetary tools to control the supply and demand for money circulating in an economy. The government can manipulate the interest rate to increase production. As a result, the interest rate can be used to control the inflation rate (Riyani, 2019).

\section{Dow Jones Islamic Market Index}

Dow Jones is a stock market index founded by The Wall Street Journal editor and founder of Dow Jones \& Company, Charles Dow. Dow made this index as a way to measure the performance of industrial components on the US stock market. This index officially began on May 26, 1986. Dow Jones stock exchange is one of the oldest US stock market indices that is still running. The total membership of the stock exchange was originally only 12 companies then expanded to 20 in 1916, and eventually added to 30 companies from 1928 until now (Amin: 2012). In more detail, Dow Jones in his website makes stock criteria that should not be included in the calculation of the Islamic Market Index (DJ Islamic Market Indices), that are companies engaged in production such as alcohol (liquor), pigs and those related to conventional capitalist financial services, the entertainment industry such as casino hotels and cinema gambling, pornographic media. The Dow Jones Islamic Market Index covers stocks from 34 countries and includes 10 economic sectors, 18 market sectors, 51 industry groups, and 89 industry subgroups. Countries included in the Dow Jones Islamic Market Index include the Indonesia Sharia 
Analysis of the effects of inflation, interest rate, dow jones Islamic Malaysia Index ...

Stock Index (ISSI.JK), the Dow Jones Islamic World Malaysia Index (DJMY25D), and the Dow Jones Islamic Market Index Japan (DJIJP).

\section{Profitability}

Profitability is the company's ability to make profits in a certain period through all the capabilities and resources they have, such as sales, cash, quantity, number of employees, and others. Profitability is a ratio or comparison to determine the company's ability to make a profit from earnings related to sales, assets, and equity-based on a certain measurement basis. Measuring the efficiency of capital use is part of profitability by comparing profit with capital or total assets used (Warno dkk, 2020).

The definition and understanding of profitability from several sources of resources mentioned that according to Sawir (2009), profitability is the net result of various policies and management decisions. This ratio provides an overview of the level of effectiveness of company management. Profitability is often used to measure the efficiency of capital use in a company by comparing the profits and capital used in operations. According to Harahap (2009), profitability illustrates the ability of companies to get profits through all capabilities and resources existing activities such as sales, cash, capital, number of employees, number of branch companies, and so forth. Meanwhile, according to Brigham and Houston (2006), profitability is the net result of a series of policies and decisions. Profitability can be determined by calculating a variety of relevant benchmarks. One of these benchmarks is with financial ratios as an analysis in analyzing financial conditions, operating results, and the level of profitability of a company.

\section{Measurement of Profitability Ratios}

Profitability ratios, according to Raharja Putra (2009), are ratios that measure a company's ability to create a level of profit both in the form of corporate profits and the economic value of sales, the company's net assets, and its capital. Types of profitability ratios are used to show how much profit derived from the performance of a company that affects the records of 
Sofyan Halim

financial statements that must be following financial accounting standards. Fatmawati, Prasetyoningrum \& Farida (2020), profitability ratios needed to record financial transactions are usually assessed by investors and creditors (banks) to assess the number of investment profits to be obtained by investors and the number of company profits to assess the company's ability to pay debts to creditors based on the level of use of assets and other resources so that it shows the level of company efficiency.

Several indicators can be used to measure profitability according to Kasmir (2014), Fahmi (2013), Syamsuddin (2009), Gitman (2008) and Brigham and Houston (2006), namely Gross Profit Margin, Operating Profit Margin, Net Profit Margin, Return on Investments, Return on Equity, Return on Common Stock Equity, Earning Per Share and Basic Earning Power.

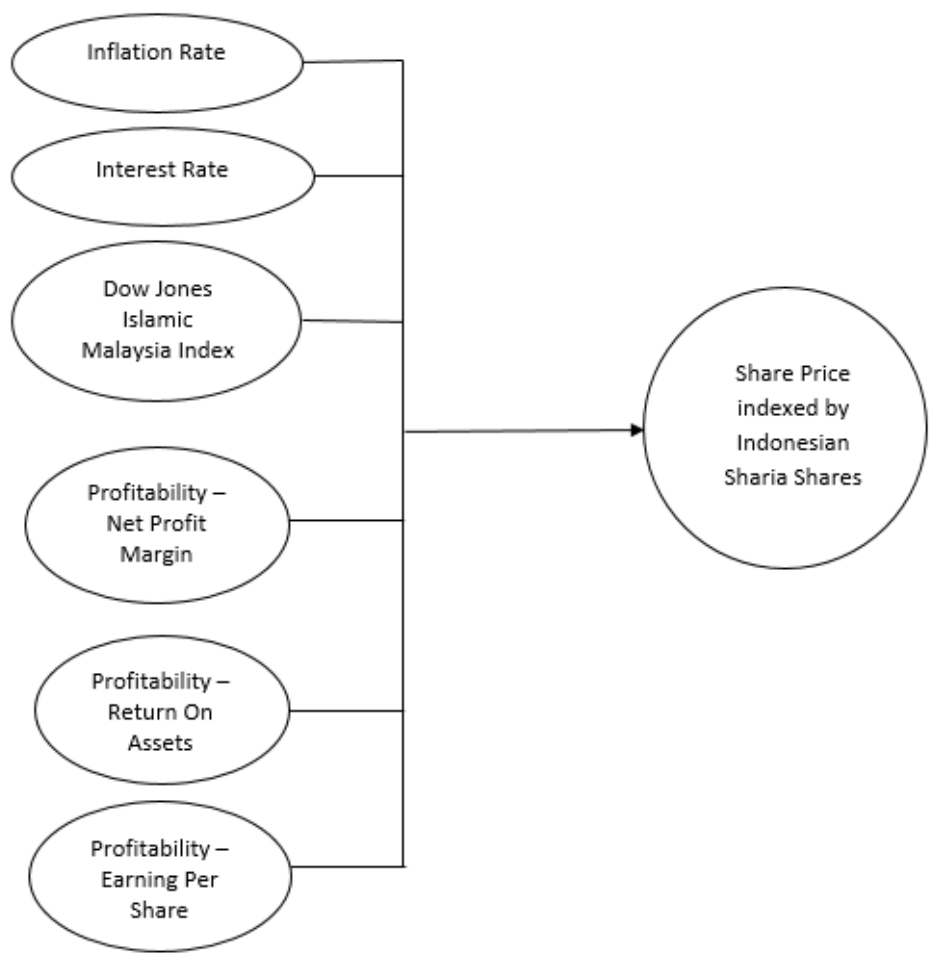

Figure 1. Research Conceptual Framework 
Analysis of the effects of inflation, interest rate, dow jones Islamic Malaysia Index ...

Based on theoretical studies, studies and empirical phenomena supported by theory, the variables in this study include: inflation rate, interest rate (BI Rate), Dow Jones Islamic Malaysia Index as the influence of external factors, and profitability as the internal factor which includes NPM, ROI/ROA and EPS, where these variables are analysed whether they affect the stock price indexed as the Indonesia Sharia Stock Index or not. Then this research can be illustrated by developing a conceptual framework shown in Figure 1.

\section{Hypothesis Development}

\section{The Effect of Inflation Rate on Indonesia Sharia Stock Indexed Price}

According to Mankiw (2014), inflation is an increase in the average price level, and price is the rate of exchange of money for goods or services. Increase in all price levels sometimes is continuous and prolonged. Inflation is a monetary phenomenon that occurs everywhere. An increase in the price of one or two items alone cannot be called inflation unless it is an increase in other goods.

Based on previous studies expressing different opinions, Irfan Syauqi Beik and Sri Wulan Fatmawati (2014) found that the inflation rate (CPI) did not have a significant relationship with JII, Ayu Utami and Leo Herlambang (2016) found that the inflation rate partially did not have a significant effect on the Jakarta Islamic Index (JII). So based on these studies, the following hypothesis is formulated:

$H_{1}$ : The inflation rate has a positive effect on stock prices indexed by Indonesia Islamic stocks

\section{The Effect of Interest Rates on Indonesia Sharia Stock Indexed Prices}

According to Boediono, the interest rate is the price for using investment funds (loan funds). Interest rate means giving a profit from the amount of funds invested or used or loaned to other parties based on economic value and calculation of time during the period of funds used by users or managers or borrowers. The rate of profit is determined by the interest rate applied. 
Sofyan Halim

Based on previous studies that are used as references for this study, there are different research results, including research by Darhwis Harahap (2016) which found that the movement of interest rates significantly affected JII stock prices; Irfan Syauqi Beik and Sri Wulan Fatmawati (2014) concluded that the BI Rate had no significant relationship with JII. Ayu Utami and Leo Herlambang (2016) in their research concluded that the interest rate partially had a significant negative effect on the Jakarta Islamic Index (JII). Then based on these researches, the following hypothesis is formulated:

\section{$\mathrm{H}_{2}$ : Interest rates have a positive effect on stock prices indexed by Indonesia Sharia Stocks}

\section{The Effect of the Dow Jones Syariah Index on Indonesia Sharia Stock Indexed Prices}

The Dow Jones Islamic Market Index covers stocks from 34 countries and covers 10 economic sectors, 18 market sectors, 51 industry groups, and 89 industry sub-groups. The countries included in the Dow Jones Islamic Market Index include the Indonesia Sharia Stock Index (ISSI.JK), the Dow Jones Islamic World Malaysia Index (DJMY25D), and the Dow Jones Islamic Market Index Japan (DJIJP).

Based on previous studies, the results were different as research by Irfan Syauqi Beik and Sri Wulan Fatmawati (2014) got the results of the VECM analysis that in the short term, only DJIJP and IPI had an impact on JII significantly. Meanwhile, in the long term, DJIEU, DJIMY and IPI had a significant positive relationship with JII. The DJIJP had a significant negative relationship with JII. Meanwhile, Retno Fuji Oktaviani (2017) concluded that the Dow Jones Islamic Europe Index had no significant effect on the Jakarta Islamic Index; The Dow Jones USA Index had a negative and significant effect on the Jakarta Islamic Index; The Japanese Dow Jones Index had no significant effect on the Jakarta Islamic Index; And the Dow Jones Islamic Malaysia Index had a positive and significant effect on the Jakarta Islamic Index. 
Analysis of the effects of inflation, interest rate, dow jones Islamic Malaysia Index ...

Based on this research, where the Dow Jones Index as the object of this research is the Dow Jones Islamic Malaysia Index, the following hypothesis is formulated:

$H_{3}$ : The Dow Jones Syairah Malaysia Index has a positive effect on stock prices indexed by Indonesia Sharia Stock

\section{Effect of Net Profit Margin on Indonesia Sharia Stock Indexed Price}

The company's profitability ratio from the calculation taking into account all costs and taxes is called the Net Profit Margin. This ratio is used to measure the net profit margin on sales and is often used to control companies in controlling costs associated with sales. NPM is usually a reference for stakeholders to determine the decisions taken in an entity.

In the previous researches, none discussed the effect of Net Profit Margin on stock prices indexed in the Indonesia Sharia Stock Index and the Jakarta Islamic Index, but in this study the following hypothesis is formulated:

$H_{4}: \quad$ NPM has a positive effect on stock prices indexed by Indonesia Sharia Stock

\section{The Effect of ROA on Indonesia Sharia Stock Indexed Stock Prices}

Yield on assets is a ratio that shows that it has a big share in creating net income. The higher the return on assets, the higher the net profit generated from each rupiah of funds attached to total assets (Hery, 2015). Then the financial reports that show a high ROA will be a good signal for investors. With a high ROA that shows the company's financial performance, investors will be interested in investing their funds.

In the previous research, which was used as a reference in this study, none discussed the effect of ROA on stock prices indexed in Indonesia Sharia Stock and the Jakarta Islamic Index, but based on the theory, the following hypothesis was formulated:

$H_{5}: \quad$ ROA has a positive effect on stock prices indexed by Indonesia Sharia Stock 
Sofyan Halim

\section{The Effect of EPS on Stock Prices}

EPS or the ratio of earnings per share is a ratio that is part of PER, which measures earnings per one share (Smart et al., 2014). This large and small JIAFR | 274 ratio will influence investors and thus affect stock prices. Information about EPS is very useful for investors to see the profit per share that will be obtained from each invested fund. The higher the company's EPS is a positive signal for investors to invest their funds.

In the previous researches, none discussed the effect of EPS on stock prices indexed as sharia stocks or the Jakarta Islamic Index. But based on the theory, the following hypothesis is formulated:

\section{$H_{6:} \quad$ EPS has a positive effect on stock prices indexed by Indonesia Sharia Stock}

\section{Research Methods}

Based on the formulation of the problem and research objectives, this type of research can be categorized as a type of quantitative research using descriptive or inferential statistics to make conclusions substantiating a hypothesis. This research is structured to prove the hypothesis of inflation, interest rates, and exchange rates as external factors, and profitability as an influential internal factor consists of NPM, ROI, and EPS which are analyzed both simultaneously and partially which affect the stock price indexed as Indonesia Sharia Stock Price Index.

The data source in this study is secondary data obtained from statistical data from the Bank Indonesia Web Site, the Central Bureau of Statistics, the Financial Services Authority, the Indonesia Stock Exchange, the Malaysia Stock Exchange, and Issuer Companies. The object of research used in this study is the issuer's data which is the sample of the listed companies and other variable data in each quarter starting in the First Quarter of 2015 to the third Quarter of 2019. In this research, the data collection was conducted through: Documentation studies are conducting library searches and reviews. Documentation studies are conducted to achieve a comprehensive 
Analysis of the effects of inflation, interest rate, dow jones Islamic Malaysia Index ...

understanding of the concepts studied. This data collection is done by reading, studying, and analyzing the data obtained carefully, then from the analysis process, the researcher concludes general problems to specific problems. Field studies are data directly from the field using the technique of collecting data through the website of the Financial Services Authority, Sharia Commercial Bank website, then the data obtained from the field are processed and analyzed with quantitative statistical methods.

The population in this study are all stocks that are encoded in the Indonesia Sharia Stock Index (ISSI) listed on the Indonesia Stock Exchange. Based on the Sharia Stock Exchange Announcement No. Peng00311/BEI.PQP/06-2019, on June 25, 2019, the number of shares indexed by ISSI was 408 shares which were classified into 11 types of business.

The sample is representative of or from the population so that the research results obtained from the sample can be generalized to the population. According to Nazir (2003), the sample survey is a procedure to take only a portion of the population and used to determine the desired traits and characteristics of the population. The sample is determined with a significance of $10 \%$ from the population of 408 and there are 7 shares not listed, then what is calculated is the basis for calculating a sample of 401 shares, then the number of samples calculated based on the slovin formula.

With this, the sample taken is 100 shares from the determined number of samples divided by 11 classifications of business sectors of shares, so that the sample to be investigated is proportionally calculated based on the type of shares listed according to ISSI. The number of samples can be calculated as shown in table 2. 
Sofyan Halim

Table 2. Determination of the Sample from the Population

\begin{tabular}{lccc}
\hline \multicolumn{1}{c}{ Business Sectors } & $\begin{array}{c}\text { Number } \\
\text { of Issuer }\end{array}$ & $\begin{array}{c}\text { Sample } \\
\text { Computation }\end{array}$ & $\begin{array}{c}\text { Number of } \\
\text { Sample }\end{array}$ \\
\hline Agriculture & 10 & $10 / 401 \times 100$ & 2 \\
Mining & 35 & $35 / 401 \times 100$ & 9 \\
Industries \& Chemical & 53 & $53 / 401 \times 100$ & 13 \\
Various Industries & 29 & $29 / 401 \times 100$ & 7 \\
Consumers Goods Industries & 39 & $39 / 401 \times 100$ & 10 \\
Property, Real Estate \& Construction & 63 & $63 / 401 \times 100$ & 16 \\
Utilities, Infrastructure \& & 56 & $56 / 401 \times 100$ & 14 \\
Transportation & & & \\
Finance & 4 & $4 / 401 \times 100$ & 1 \\
Trading. Services \& Investment & 109 & $109 / 401 \times 100$ & 27 \\
Perusahaan Public Companies & 3 & $3 / 401 \times 100$ & 1 \\
Not Listed -7 & 7 & $0 / 401 \times 100$ & 0 \\
\hline \multicolumn{1}{c}{ Total } & $\mathbf{4 0 8}$ & $\mathbf{1 0 0}$ \\
\hline
\end{tabular}

\section{Results and Discussion}

\section{Multiple Regression Analysis}

The data in this study were processed by doing two regressions; first with multiple regression and second with regression with Cochrane Orcutt. The results of data processing with multiple regression test are constrained by autocorrelation problems because based on data analysis of Durbin Watson (DW) has a very low value. It can be seen in the table 3 .

Table 3. Regression without Cochrane Orcutt Result

\begin{tabular}{|c|c|c|c|c|c|c|}
\hline \multicolumn{7}{|c|}{ Coefficients $^{a}$} \\
\hline \multirow{2}{*}{\multicolumn{2}{|c|}{ Model }} & \multicolumn{2}{|c|}{$\begin{array}{l}\text { Unstandardized } \\
\text { Coefficients }\end{array}$} & \multirow{2}{*}{$\begin{array}{c}\text { Standardized } \\
\text { Coefficients } \\
\text { Beta }\end{array}$} & \multirow[b]{2}{*}{$\mathbf{t}$} & \multirow[b]{2}{*}{ Sig. } \\
\hline & & B & Std. Error & & & \\
\hline 1 & (Constant) & 5.454 & 2.709 & & 2.013 & .044 \\
\hline & $\mathrm{x} 1$ & -.024 & .088 & -.006 & -.269 & .788 \\
\hline & $x 2$ & -.021 & .025 & -.019 & -.839 & .402 \\
\hline & $x 4$ & -.004 & .002 & -.056 & -2.482 & .013 \\
\hline & $1 \times 3$ & .048 & .409 & .003 & .118 & .906 \\
\hline & $1 \times 6$ & .420 & .018 & .573 & 22.770 & .000 \\
\hline & Ix5 & -.172 & .023 & -.186 & -7.397 & .000 \\
\hline
\end{tabular}

a. Dependent Variable: $y$ 
Analysis of the effects of inflation, interest rate, dow jones Islamic Malaysia Index ...

Table 4. Autocorelassion without Cochrane Orcutt

\begin{tabular}{lccccc}
\multicolumn{7}{c}{ Model Summary $^{\mathrm{b}}$} \\
\hline Model & $\mathbf{R}$ & $\mathbf{R}$ Square & $\begin{array}{c}\text { Adjusted R } \\
\text { Square }\end{array}$ & $\begin{array}{c}\text { Std. Error of } \\
\text { the Estimate }\end{array}$ & Durbin-Watson \\
\hline 1 & $.523^{\mathrm{a}}$ & .274 & .271 & 1.09255 & .308 \\
\hline a. Predictors: (Constant), $1 \times 5,1 \times 3, \times 4, \times 1, \times 2,1 \times 6$ & & \\
b. Dependent Variable: ly & & & &
\end{tabular}

Based on the table 4, it was found that the value of Watson Durbin (DW) is very low, which is equal to 0.308 . That value is far from a safe value, which is around 1.9-2.0. So to test the classic assumption of autocorrelation in parts without Cochrane Orcutt is not acceptable. In addition to violating the autocorrelation test, this section also violates the heteroscedasticity test.

Furthermore, this study was conducted using regression with Cochrane Orcutt because the data were free from autocorrelation because the Durbin Watson (DW) value increased significantly and was relatively safe with a value of 1.978 (see table 8). Furthermore, the researchers analyzed the data with Cochrane Orcutt, in the analysis and data testing, in essence, the data were transformed by looking for the Lag_e value that came from the residual value regression, then transforming the variables in this study. So that the data processing results in the table were obtained as presented in table 5 .

Table 5. Regression Analysis with Cochrane Orcutt Result

Coefficients $^{\mathrm{a}}$

\begin{tabular}{|c|c|c|c|c|c|c|}
\hline \multirow{2}{*}{\multicolumn{2}{|c|}{ Model }} & \multicolumn{2}{|c|}{$\begin{array}{l}\text { Unstandardized } \\
\text { Coefficients }\end{array}$} & \multirow{2}{*}{$\begin{array}{c}\text { Standardized } \\
\text { Coefficients } \\
\text { Beta }\end{array}$} & \multirow[b]{2}{*}{$t$} & \multirow[b]{2}{*}{ Sig. } \\
\hline & & B & Std. Error & & & \\
\hline \multirow[t]{7}{*}{1} & (Constant) & 30.994 & 29.649 & & 1.045 & .296 \\
\hline & Lag_X1 & 29.782 & 35.024 & .021 & .850 & .395 \\
\hline & Lag_X2 & 54.790 & 28.820 & .050 & 1.901 & .057 \\
\hline & Lag_X3 & .634 & .310 & .052 & 2.048 & .041 \\
\hline & Lag_X4 & .000 & .005 & -.001 & -.056 & .955 \\
\hline & Lag_X5 & .006 & .049 & .003 & .122 & .903 \\
\hline & Lag_X6 & .065 & .055 & .028 & 1.194 & .233 \\
\hline
\end{tabular}

a. Dependent Variable: Lag_y 
Sofyan Halim

It is known that the value of $t$-table with the amount of data 1881 is equal to 1.6457, and compared with table 4-5, it can be explained as follows: Variable X1 has a t-statistic value of 0.850 , because the t-statistic value $<\mathrm{t}$ table, then there is no effect between the $\mathrm{X} 1$ variable on the $\mathrm{Y}$ variable. Variable X2 has a t-statistic value of 1.901 , because t-statistic value $>$ t-table, then there is an influence between the $\mathrm{X} 2$ variable on the $\mathrm{Y}$ variable. Variable $\mathrm{X} 3$ has a t-statistic value of 2.048 due to the $\mathrm{t}$-statistic value $>\mathrm{t}$-table, then there is an influence between the X3 variable on the $\mathrm{Y}$ variable. Variable $\mathrm{X} 4$ has a t-statistic value of -0.056 , because the $\mathrm{t}$-statistic value $<\mathrm{t}$-table, then there is no effect between the X4 variable on the Y variable. Variable X5 has a t-statistic value of 0.122 , because the t-statistic value $<$ t-table, then there is no effect between the X5 variable on the Y variable. Variable X6 has a t-statistic value of 1.194 , because the t-statistic value $<t$-table, then there is no effect between the X6 variable on the Y variable.

The results of data analysis processing show that the F test is used to see whether or not the influence of the independent variables together on the dependent variable and to test whether the model used is fixed or not.

Table 6. Anova

ANOVA $^{\mathrm{a}}$

\begin{tabular}{|c|c|c|c|c|c|}
\hline Model & Sum of Squares & df & Mean Square & $\mathbf{F}$ & Sig. \\
\hline 1 Regression & 11414894.083 & 6 & 1902482.347 & 2.835 & $.009^{b}$ \\
\hline Residual & 1254051768.316 & 1869 & 670974.729 & & \\
\hline Total & 1265466662.399 & 1875 & & & \\
\hline
\end{tabular}

a. Dependent Variable: Lag_y

b. Predictors: (Constant), Lag_X6, Lag_X5, Lag_X4, Lag_X2, Lag_X1, Lag_X3

Table 7. Regression Analysis Result

Model Summary

\begin{tabular}{lcccr}
\hline Model & $R$ & R Square & Adjusted R Square & Std. Error of the Estimate \\
\hline 1 & $.095^{a}$ & .009 & .006 & 819.13047 \\
\hline a. Predictors: (Constant), Lag_X6, Lag_X5, Lag_X4, Lag_X2, Lag_X1, Lag_X3
\end{tabular}


Analysis of determination in multiple linear regression is used to determine the percentage contribution of the influence of independent variables (X1, X2, X3, X4, and X6) simultaneously against the dependent variable (Y). This coefficient shows how big the percentage of variation of the independent variables used in the model can explain the variation of the dependent variable. Based on the results of the regression analysis, a summary model output can be constructed that can be presented in table 7 .

Based on data analysis, the summary model is obtained where the amount of Adjusted R Square is 0.006. It indicates that the contribution of variables $\mathrm{X} 1, \mathrm{X} 2, \mathrm{X} 3, \mathrm{X} 4, \mathrm{X} 5$, and $\mathrm{X} 6$ reached $0.6 \%$, while the remaining $90.4 \%$ was determined by other factors outside the model that were not detected in this research.

\section{Classical Assumption Test}

Autocorrelation aims to see the relationship between the residuals of observations with other observational residuals. The present data were influenced by data from previous periods. Nevertheless, it is still possible to find autocorrelation in data that is between objects. If there is a correlation, it means that there is an autocorrelation problem, to find out whether the model is experiencing autocorrelation the Durbin-Watson test is used (Gujarati, 2006).

Based on the output table 8, it is known that the Durbin-Watson (DW) value is 1.978. Furthermore, this value will be compared with the value of the Watson Durbin table at a significance of 5\% (0.05) with the formula (k; n). As for the number of independent variables is 6, while the number of samples $\mathrm{N}$ $=1881$. Then found the dL value of 1.9192 and the value of $\mathrm{dU}$ of 1.9298 . Durbin-Watson (DW) value of 1.978 is greater than the upper limit (dU) which is 1.9192 and less than (4-Du) 4-1.9298 $=2.0702$. It can be concluded that there are no problems or symptoms of autocorrelation. So that the above research can be continued. 
Sofyan Halim

Table 8. Autocorrelation Test

\begin{tabular}{|c|c|c|c|c|c|}
\hline \multicolumn{6}{|c|}{ Model Summary ${ }^{b}$} \\
\hline Model & $\boldsymbol{R}$ & $R$ Square & $\begin{array}{l}\text { Adjusted } R \\
\text { Square }\end{array}$ & $\begin{array}{l}\text { Std. Error of the } \\
\text { Estimate }\end{array}$ & Durbin-Watson \\
\hline 1 & $.095^{a}$ & .009 & .006 & 819.13047 & 1.978 \\
\hline
\end{tabular}

Table 9. Normality Test

\begin{tabular}{llr}
\multicolumn{3}{c}{ One-Sample Kolmogorov-Smirnov Test } \\
\hline \multicolumn{2}{c}{ Unstandardized Residual } \\
\hline$N$ & & 1876 \\
Normal Parameters ${ }^{a, b}$ & Mean & .0000000 \\
& Std. Deviation & 817.81881231 \\
Most Extreme Differences & Absolute & .314 \\
& Positive & .266 \\
& Negative & -.314 \\
Test Statistic & & .314 \\
Asymp. Sig. (2-tailed) & $.000^{c}$ \\
\hline a. Test distribution is Normal. & \\
b. Calculated from data. & \\
c. Lilliefors Significance Correction. &
\end{tabular}

Tests on the normality of the data have been carried out by showing the results that the data are not normally distributed, as shown in Table 9. Based on the test results, it appears that testing shows all variables have abnormal distribution values, which is due to Asym Sig. less than 5\% (0.05). But based on the Central Limit Theorem assumption which states that for samples that are more than $30(n \geq 30)$ the distribution of samples is considered close to the normal distribution (Dielman, 1961). So, even though testing from the classic assumptions in the form of normality tests show that all data are not normally distributed, but because of observations of more than $30(n \geq 30)$ then the data is still considered normal since the study uses 1881 samples originating from issuers whose shares were indexed as sharia shares on the Indonesia Stock Exchange. 
Analysis of the effects of inflation, interest rate, dow jones Islamic Malaysia Index ...

Multicollinearity test aims to test whether the regression model found a correlation between independent or independent variables. To test the presence of multicollinearity can be seen through the value of the Variance Inflantion Factor (VIF) and tolerance value for each independent variable. If the tolerance value is above 0.10 and VIF $<10$, it is said that there are no symptoms of multicollinearity. The results of the calculation of VIF values. For multicollinearity testing between fellow independent variables can be seen in table 10.

Based on the multicollinearity test results, as seen in table 10, in the VIF column, VIF value for variable X1 is 1,122 , VIF value for variable X2 is 1,321 , VIF value for variable X3 is 1,196 , VIF value for variable X4 is 1,001 , VIF value for variable X4 is 1,005 and VIF value for variable X6 is 1,002 . Because the VIF value is of the six variables there are no more than 5 or 10 , and referring to Duwi Priyatno (2009), in the SPSS book for Correlation, Regression, and Multivariate Analysis states in most researchs that if Tolerance is more than 0.1 and VIF is less than 10 then multicollinearity does not occur. So it can be said that in this research there was not occur multicollinearity in the six independent variables. Based on the terms of the classical assumptions of linear regression with Ordinary Left Square, a good linear regression model is free from multicollinearity. Thus, the above model has been freed from the presence of multicollinearity.

Table 10. Multicollinearity Test

Coefficients ${ }^{a}$

\begin{tabular}{|c|c|c|c|c|c|c|c|c|}
\hline \multirow{2}{*}{\multicolumn{2}{|c|}{ Model }} & \multicolumn{2}{|c|}{$\begin{array}{l}\text { Unstandardized } \\
\text { Coefficients }\end{array}$} & \multirow{2}{*}{$\begin{array}{c}\text { Standardized } \\
\text { Coefficients } \\
\text { Beta }\end{array}$} & \multirow[b]{2}{*}{$\mathbf{T}$} & \multirow[b]{2}{*}{ Sig. } & \multicolumn{2}{|c|}{$\begin{array}{c}\text { Collinearity } \\
\text { Statistics }\end{array}$} \\
\hline & & B & Std. Error & & & & Tolerance & VIF \\
\hline \multirow[t]{7}{*}{1} & (Constant) & 30.994 & 29.649 & & 1.045 & .296 & & \\
\hline & Lag_X1 & 29.782 & 35.024 & .021 & .850 & .395 & .891 & 1.122 \\
\hline & Lag_X2 & 54.790 & 28.820 & .050 & 1.901 & .057 & .757 & 1.321 \\
\hline & Lag_X3 & .634 & .310 & .052 & 2.048 & .041 & .836 & 1.196 \\
\hline & Lag_X4 & .000 & .005 & -.001 & -.056 & .955 & .999 & 1.001 \\
\hline & Lag_X5 & .006 & .049 & .003 & .122 & .903 & .995 & 1.005 \\
\hline & Lag_X6 & .065 & .055 & .028 & 1.194 & .233 & .998 & 1.002 \\
\hline
\end{tabular}

a. Dependent Variable: Lag_y 
Sofyan Halim

Table 11. Heteroscedasticity Test Results

JIAFR | 282

\begin{tabular}{|c|c|c|c|c|c|c|}
\hline \multicolumn{7}{|c|}{ Coefficients $^{\mathrm{a}}$} \\
\hline & & \multicolumn{2}{|c|}{$\begin{array}{l}\text { Unstandardized } \\
\text { Coefficients }\end{array}$} & \multirow{2}{*}{$\begin{array}{c}\text { Standardized } \\
\text { Coefficients } \\
\text { Beta }\end{array}$} & \multirow[b]{2}{*}{$\mathrm{T}$} & \multirow[b]{2}{*}{ Sig. } \\
\hline \multicolumn{2}{|c|}{ Model } & B & Std. Error & & & \\
\hline \multirow[t]{7}{*}{1} & (Constant) & .437 & .104 & & 4.178 & .000 \\
\hline & Lag_X1 & .263 & .183 & .082 & 1.438 & .151 \\
\hline & Lag_X2 & .039 & .042 & .052 & .919 & .359 \\
\hline & Lag_X3 & .000 & .000 & .019 & .338 & .736 \\
\hline & Lag_X4 & -.006 & .003 & -.091 & -1.685 & .093 \\
\hline & Lag_X5 & $-5.091 E-5$ & .000 & -.041 & -.767 & .443 \\
\hline & Lag X6 & .001 & .001 & .060 & 1.102 & .271 \\
\hline
\end{tabular}

Heteroscedasticity test aims to test whether in a regression model there is an unequal variance from the residuals of one observation to another. If the variance from one observation residual to another observation is fixed, then it is called homocedasticity, and if different, it is called heteroscedasticity. The test results can be seen in table 11. Based on the table 11, it can be seen that the calculation results of each variable show the level of $\operatorname{sig}>\alpha$, or the level of significance $>0.05$, which means there is heteroscedasticity, and it can be concluded that the null hypothesis is accepted. It means that there has been a homoscedasticity situation in the regression model and there is no longer any deviation from the heteroscedasticity assumption, so that the model becomes efficient again and the conclusions drawn are uncertain. Conversely, if the significance $<0.05$, it means that there is no heteroscedasticity. Based on the results of processing and analysis of the data described in table 11, it can be seen that for the instrument variable, the level of inflation (X1) is obtained Sig 0.151 , meaning that Sig $0.151>0.05$ for the instrument. Interest rate (X2) shows sig 0.359, meaning that Sig $0.359>0.05$. The variable instrument of Dow Jones Islamic Malaysia Index (X3) shows 0.736 , meaning that Sig $0.736>$ 0.05 . Then the instrument variable NPM (X4) shows that 0.093 , which means that Sig $0.093>0.05$. On the variable ROA instrument (X5), it is 0.443, meaning that GIS 0.443>0.05 and on the EPS instrument (X6) it shows a value of 0.271 , meaning that Sig $0.271>0.05$. Of the six variables, it shows that 
Analysis of the effects of inflation, interest rate, dow jones Islamic Malaysia Index ...

the value of the six variables is all Sig Values $>0.05$. So, it means that this study does not experience heteroscedasticity problems.

\section{Analysis of External Effects on Stock Prices}

Based on the explanation of the results of the research above, it can be seen that the external influences understudy, namely inflation, interest rates, and the Dow Jones Islamic Malaysia Index, can be explained that:

Based on the analysis of the multiple regression equation, the data obtained from the analysis results are shown in table 5 as follows: 1) A constant value of 30.994 indicates that if the dependent variable is the issuer's stock price is zero then the issuer's stock price is a constant of 30.994 . 2) The inflation coefficient of 29.782 indicates that an increase in inflation in one unit of numbers will result in an increase in the issuer's stock price of work by 29,782 units assuming other variables are constant. 3) An interest coefficient value of 54.790 indicates that an increase in interest rates in one unit of numbers will increase in the issuer's stock price of 54.790 units assuming other variables are constant. 4) The Dow Jones Islamic Malaysia index coefficient value of 0.634 indicates that an increase in Dow Jones Islamic Malaysia index in one unit of numbers will increase in the issuer's stock price of 0.634 units assuming other variables are constant.

The results of the analysis of the T-test show that: 1) Variable X1 has a tstatistic value smaller than t-table, so it shows that there is no effect of the inflation rate as variable $\mathrm{X} 1$ on the issuer's stock price as variable Y. 2) Variable X2 has a t-statistic value greater than t-table, so it shows that the influence of the interest rate as variable X2 on the issuer's stock price as variable Y. 3) Variable X3 has a t-statistic value greater than t-table, so it shows the influence of the Dow Jones Islamic Malaysia Index as the X3 variable on the issuer stock price as the $\mathrm{Y}$ variable.

Based on table 5, the significant test results are as follows: 1) Variable X1 has a significant value of 0.395 . It shows that there is no effect of the inflation rate as variable $\mathrm{X} 1$ on the issuer's stock price as variable $\mathrm{Y}$, because it shows a significance value greater than 0.05 . 2) Variable X2 has a significance value of 
Sofyan Halim

0.057. So, it shows that there is no effect of the interest rate as variable $\mathrm{X} 2$ on the issuer's stock price as variable $Y$, because the significance value is greater than 0.05. 3) Variable X3 has a significance value of 0.041 which shows the

JIAFR | 284 influence of the Dow Jones Islamic Malaysia Index as variable X3 on the issuer's stock price as variable $Y$ because the significance value is less than 0.05 .

\section{Analysis of Internal Effects Against Stock Prices}

Based on the results of the multiple regression analysis described above, it can be seen that the internal effect understudy is the level of profitability which includes Net Profit Margin, Return on Assets, and Earning Per Share that can be explained that:

Based on the analysis of the multiple regression equation, the data obtained from the analysis results are shown in table 5, as follows: 1) An NPM coefficient of 0,000 indicates that an increase in NPM in one unit of numbers will increase in the issuer's stock price of 0,000 units assuming other variables are constant. 2) ROA coefficient value of 0.006 indicates that an increase in ROA in one unit of numbers will result in an increase in the issuer's stock price by 0.006 units assuming other variables are constant. 3 ) EPS coefficient value of 0.065 indicates that an increase in EPS in one unit of numbers will result in an increase in issuer stock prices by 0.065 units assuming other variables are constant.

The results of the analysis of the T-test show that: 1) Variable X4 has a tstatistic value smaller than t-table, so it shows that there is no influence between the NPM variable on the issuer's stock price as the Y variable. 2) Variable X5 has a t-statistic value smaller than t-table, so it shows that there is no influence between the ROA variable on the issuer's stock price as a variable Y. 3) Variable X6 has a t-statistic value smaller than t-table, so there is no effect between the EPS variable on the issuer's stock price as a Y variable.

Based on table 4-5 above shows the significant test results as follows: 1) Variable X4 has a significant value of 0.955 , this shows that there is no influence of the NPM variable on the issuer's stock price as Y variable, 
because it shows a significance value greater than 0.05 . 2) Variable $\mathrm{X} 5$ has a significance value of 0.903 , so it shows that there is no influence of the ROA variable on the issuer's stock price as $\mathrm{Y}$ variable, because the significance value is greater than 0.05 . 3) Variable X6 has a significance value of 0.233 , so it shows there is an influence of the EPS variable on the issuer's stock price as $Y$ variable because the significance value is smaller than 0.05 .

\section{Analysis of Regression}

Coefficient Test Together based on the data table 6 above shows the results of data processing with the $\mathrm{F}$ Test gets a significant value at 0.009 . It shows the value of sig $0,000<0.05$ ), thus indicating that the regression equation obtained is reliable or the model used is fixed. It means that the independent variable can explain the dependent variable together.

\section{Analysis of Determination (R2)}

Based on the data in table 7 about the Coefficient of Determination (R2) shows that the amount of Adjusted R Square is 0.006 , then it indicates that the contribution of variables $\mathrm{X} 1, \mathrm{X} 2, \mathrm{X} 3, \mathrm{X} 4, \mathrm{X} 5$, and $\mathrm{X} 6$ is $0.6 \%$, while the rest is $90.4 \%$ is determined by other factors outside the model that were not detected in this study. So, it can be interpreted that the stock price of the issuers studied in the majority is not influenced by the variables studied.

\section{Hypothesis Testing}

Analysis of hypothesis testing using the results of the $\mathrm{T}$ test, as explained above, the $t$ table value of the total data is 1881. It is known that the $t$ table value is 1.6457 , then hypothesis testing is carried out on all variables as follows:

\section{Testing the Regression Coefficient for Variable X1 (Inflation Rate)}

The variable $\mathrm{X} 1$ has a t-statistic value of 0.850 , so that the $\mathrm{t}$-statistic value $<\mathrm{t}$-table is $0.850<1.6457$. According to Mankiw, inflation is an increase in the average price level, and price is the rate at which money is exchanged for 
Sofyan Halim

goods or services. Increases in the entire price level are sometimes continuous and prolonged. Inflation is a monetary phenomenon that occurs anywhere. An increase in the price of one or two goods alone cannot be called inflation unless it extends (or causes an increase) to other goods. So that the research was conducted.

Hypothesis 1 (H1) states that the inflation rate variable will affect the indexed stock price because of the Indonesia Sharia Stock Price Index. But based on the $t$ test, it shows that the $t$-statistic value $<t$-table. Therefore, hypothesis 1 (H 1) is rejected, which means that the inflation rate has no effect on stock price movements indexed by Indonesia Sharia Stock.

\section{Test the Regression Coefficient for Variable X2 (Interest Rates)}

The variable $\mathrm{X} 2$ is the interest rate. Based on the results of the $t$ test, it has a t-statistic value of 1.901 , so that the t-statistic> t-table value is $1.901>$ 1.6457 .

The function of interest rates in the economy according to Sunariah (2013) is: 1) As an attraction for investors to invest their funds. 2) The interest rate can be used as a means of control for the government over direct funds or investment in economic sectors. 3) The interest rate can be used as a monetary tool in order to control the supply and demand for money in circulation in an economy. 4) The government can manipulate the interest rate to increase production, as a result the interest rate can be used to control the inflation rate.

Hypothesis $2(\mathrm{H} 2)$ in this study is the interest rate has a positive effect on stock prices indexed as Indonesia Sharia Stock. The results of the hypothesis test show the value of $t$-statistic $>\mathrm{t}$-table. The interest rate variable (X2) shows that it affects the stock price which is indexed as Indonesia Sharia Stock Price (variable Y), so the hypothesis is accepted. It means that the interest rate has a positive influence on stock price movements indexed as the Indonesia Sharia Stock Index. 
Analysis of the effects of inflation, interest rate, dow jones Islamic Malaysia Index ...

\section{Test the Regression Coefficient for Variable X3 (the Dow Jones Islamic Malaysia} Index)

The variable $\mathrm{X} 3$ has a t-statistic value of 2.048 , so it shows that the $\mathrm{t}$ statistic value $>t$-table value is $2.048>1.6457$. Dow Jones Sharia on its website makes criteria for stocks that are categorized as sharia stocks which are included in the calculation of the Islamic Market Index (DJ Islamic Market Indexes), namely listed companies that are not allowed to produce such as alcohol (liquor), products made from pigs, industry associated with conventional capitalist financial services, entertainment industry such as hotel casinos and cinema gambling, pornographic media. The Dow Jones Islamic Market Index includes stocks from 34 countries, and covers 10 economic sectors, 18 market sectors, 51 industry groups and 89 industry subgroups. Countries that are included in the Dow Jones Islamic Market Index include the Indonesia Sharia Stock Index (ISSI.JK), the Dow Jones Islamic Market Index Japan (DJIJ), and the Dow Jones Islamic World Malaysia Index (DJMY25D) or the Dow Jones Islamic Malaysia Index. In this study, the variable X3 used is the Dow Jones Islamic Malaysia Index.

Hypothesis 3 (H 3) is that the Dow Jones Islamic Malaysia Index has a positive effect on stock prices indexed as the Indonesia Sharia Stock Price Index. Based on the $t$ test shows that the value of $t$-statistic> $t$-table, then hypothesis 3 on the Dow Jones Islamic Malaysia Index (X3) variable affects the indexed stock price which is accepted as the Indonesia Sharia Stock Price Index. So, it can be interpreted that has a positive effect on stock price movements indexed as the Indonesia Sharia Stock Index.

\section{Testing the Regression Coefficient for Variable X4 (NPM)}

The variable $\mathrm{X} 4$ has a t-statistic value of -0.056 , so that the t-statistic value $<\mathrm{t}$-table is $-0.056<1.6457$. Net Profit Margin is the Profitability Ratio used to measure the net profit margin on sales and is often used to evaluate the efficiency of a company in controlling expenses related to sales. This NPM ratio is the profitability ratio required for recording financial transactions which is generally assessed by investors and creditors (banks) to assess the 
Sofyan Halim

JIAFR | 288

amount of investment return that will be obtained by investors and the amount of company profit to assess the company's ability to pay debts to creditors based on the level of asset usage. and other resources so that the company's efficiency level can be seen. The higher the NPM ratio, the special note for investors and creditors for the business.

Therefore, hypothesis 4 (H4) is made by showing that the Net Profit Margin has a positive effect on the stock price indexed as the Indonesia Sharia Stock Index. Based on the results of the t-test shows t-statistic $<\mathrm{t}$-table, so the hypothesis of the variable $\mathrm{X} 4$ has an effect on the price. Indonesia Sharia Stock indexed shares are rejected which indicates that the Net Profit Margin has no effect on stock price movements indexed as the Indonesia Sharia Stock Index.

\section{Test the Regression Coefficient for Variable X5 (ROA)}

The variable X5 has a t-statistic value of 0.122 , so that the t-statistic value $<t$-table is $0.122<1.6457$. ROA is the ratio of the measurement of the company's overall ability to generate profits with the total number of assets available in the company. This ratio sees the extent to which the investment that has been invested is able to provide returns as expected. And the investment is actually the same as the invested company's assets. ROA is a ratio that shows the results (return) on the total assets used in the company. ROA is also a measure of management effectiveness in managing investments. This ratio is a measure of investors in making investments. There are several indicators that can be used to measure profitability according to Kasmir (2014), Fahmi (2013), Syamsuddin (2009), Gitman (2008) and Brigham and Houston (2006), one of which is Return on Investement/Return on Asset, in general, investors will see a high ROA, which will be a consideration for investing.

Hypothesis 5 (H5) is that ROA has a positive effect on stock prices indexed as the Indonesia Sharia Stock Index. Based on the $t$ test on variable $\mathrm{X} 5$, the value of t-statistic <t-table, so that the hypothesis of variable X5 affects the indexed stock price of Indonesia Sharia Stock Price is rejected. It means 
Analysis of the effects of inflation, interest rate, dow jones Islamic Malaysia Index ...

that ROA does not have a positive effect on stock price movements indexed as the Indonesia Sharia Stock Index.

\section{Test the Regression Coefficient for Variable X6 (EPS)}

The variable X6 has a t-statistic value of 1.194, so that the t-statistic value JIAFR | 289 $<\mathrm{t}$-table is $1.194<1.6457$. Earning Per Share Ratio or the Ratio Per Share or also known as the Book Value Ratio is used to measure the success of management in obtaining benefits for shareholders. There are several indicators that can be used to measure profitability according to Kasmir (2014), Fahmi (2013), Syamsuddin (2009), Gitman (2008) and Brigham and Houston (2006), one of which is Earning Per Share. Then if the EPS ratio shows a low value, it means that management has not succeeded in providing the best results for shareholders. On the contrary, with a high ratio, the welfare of shareholders increases because the profits they get that is a high rate of return. Earnings Per Share or EPS is obtained from the profit available to common stockholders divided by the average number of ordinary shares outstanding.

Hypothesis 6 (H6) states that Earning Per Share has a positive effect on stock prices indexed as the Indonesia Sharia Stock Index. However, based on the t-test, it shows the value of t-statistic <t-table, so the hypothesis of the EPS variable (X6) has a positive effect on the indexed stock price. Indonesia Sharia Stock Price is rejected, so it means that the variable Earning Per Share does not have a positive effect on stock price movements indexed as the Indonesia Sharia Stock Index.

\section{Conclusion}

As explained in the research analysis, this study examines and analyzes whether external and internal factors of the issuer's shares are indexed as the Indonesia Sharia Stock Price Index. The external factors are categorized as inflation, Bank Indonesia interest rates, and the Dow Jones Islamic Malaysia Index. While those categorized as internal factors in this study are the 
Sofyan Halim

Profitability Ratio which includes Net Profit Margin, Return on Assets, and Earning Per Share.

Based on the results of the study from this analysis, it can be concluded that only the inflation rate as an external factor does not affect the stock price of the issuer, while the interest rates of Bank Indonesia, as well as the Dow Jones Islamic Malaysia Index, affect the fluctuations in stock prices indexed as the Indonesia Sharia Stock Index. However, based on the significance test of Bank Indonesia's Interest Rate factors, the conclusion does not affect the stock price. Meanwhile, internal factors, which include Net Profit Margin, Return on Assets, and Earning Per Share, does not significantly influence fluctuations in share prices indexed as the Indonesia Sharia Stock Index.

Based on the results of data processing with the F Test or Analysis of the Regression Coefficient Test Together shows that the regression equation obtained can be relied on in the test. So, it can be interpreted that the independent variables studied are able to explain the dependent variables together.

Likewise, based on the analysis of the coefficient of determination (R2), the amount of Adjusted R Square shows that the contribution of the independent variable studied is only $0.6 \%$, meaning that the effect is not too significant, but other factors outside the model that are not detected in this study are interpreted as influencing the stock price. Therefore, it can be interpreted that the stock price of the issuer indexed as the Indonesia Sharia Stock Price Index is largely not influenced by the independent variables studied.

Based on the conclusions explained above, the research that has been done is far from perfect, so that further research is needed so that to get an answer, what factors significantly influence the fluctuation and stock price development of listed companies as Sharia Stock Indices, and develop research by examining the variables that have not been analyzed in this study, in addition to the research period as well as the analyzed sample conducted at different periods and samples. 
Analysis of the effects of inflation, interest rate, dow jones Islamic Malaysia Index ...

Hopefully, the results of this research can be useful for all stakeholders with an interest in the capital market, especially sharia-based investors, who can invest calmly and comfortably. Likewise, this research is expected to bring benefits to society in general according to the objectives the benefits that have been stated in this research, and it is hoped that this research can also be a reference for further researchers to be able to perfect and update the development of subsequent research.

\section{References}

Ayu, T. U., \& Leo, H. (2016). Pengaruh Varianble Makro Ekonomi terhadap Indeks Jakarta Islamic Index (III) Periode Januari 2010-November 2015. Fakultas Ekonomi dan Bisnis Universitas Airlangga.

Boediono. (2014). Seri Sinopsis Pengantar Ilmu - No. 5 Ekonomi Makro, Yogyakarta: BPFE.

Brigham, E. F., \& Houston. (2006). Fundamental of Financial Management: Dasar-Dasar Manajemen Keuangan, Jakarta: Salemba Empat.

Darwis, H. (2016) Analisis Faktor-faktor yang mempengaruhi Harga Saham Jakarta Islamic Index (JII). Jurnal Analytica Islamica, 5(2), 342-367.

Dornbusch, R., \& Stanley, F. (1992). Makroekonomi Edisi Keempat, Jakarta: Erlangga.

Eduardus, T. (2010). Portofolio dan Investasi Teori dan Aplikasi Edisi 1, Yogyakarta: Kanisius.

Fitriani. (2110). Analisa Pengaruh Krisi Global Financial terhadap Jakarta Islamic Index (JII) dan Index Harga Saham Gabungan (IHSG). Jurnal Ekonomi \& Keuangan Islam, 2(1), 1-12.

Fitriana, R., Yulianto, A., \& Solikhah, B. (2019). Are characteristics of sharia supervisory boards able to improve the performance of islamic banking? Journal of Islamic Accounting and Finance Research, 1(1), 124. https://doi.org/10.21580/jiafr.2019.1.1.3753.

Fatmawati, E. D., Prasetyoningrum, A. K., \& Farida, D. N. (2020). Dampak Profitabilitas, Likuiditas dan Pengungkapan Islamic Social Reporting Terhadap Return Saham. El Dinar, 8(2), 67-86.

Greuning, H. V., \& Iqbal, Z. (2011). Analisis Risiko Perbankan Syariah, Jakarta: Salemba Empat. 
Sofyan Halim

Hamdy, H. (2010). Manajemen Keuangan Internasional, Jakarta: Mitra Wacana Media.

Harahap, S. S. (2009). Teori Kritis Laporan Keuangan, Jakarta: Bumi Aksara.

JIAFR | 292

Halim, S. (2020). Effect of Financing in Sharia Business Units on Profitability and Financing Risk Management. Journal of Islamic Economics and Social Science (JIESS), 1(1), 11-27.

https://www.ojk.go.id/

https://www.idx.co.id/idx-syariah/indeks-saham-syariah/

https://www.kajianpustaka.com

https://www.researchgate.net/publication/323659979_Cointegration_Betw een_Macroeconomic_Variables_and_Sectoral_Indices_Movement_in_Bu rsa_Malaysia.

Ihyaul. U., \& Juanda, A. (2016). Metodologi Penelitian Akuntansi, Aditya Media Publishing.

Irfan, S. B., \& Fatmawati, S. W. (2014). Pengaruh Indeks Harga Saham Syariah International dan Variable Makro Ekonomi terhadap Jakarta Islamic Index (JII). Al-Iqtishad, 6(2).

Jaafar P., \& Ahmad, I. (2017). Cointegration between Macro Economic Variable and Sectoral Indices Movement in Bursa Malaysia. GIAT, 7(1).

Judisseno, R. K. (2002). Sistem Moneter dan Perbankan di Indonesia, Jakarta: Gramedia Pustaka Utama.

Kasmir. (2014). Analisis Laporan Keuangan, Jakarta: Raja Grafindo Persada.

Krugman, P. R., Obstfeld, M., \& Melitz, M. J. (2012). International Economics: Theory and Policy. Ninth Edition, Boston: Pearson Education Inc.

Krugman, P., \& Maurice, O. (1999). Ekonomi Internasional: Teori Dan Kebijakan, Jakarta: Raja Grafindo Perkasa.

Kuncoro, M. (2001). Metode Kuantitatif Teori dan Aplikasi Untuk Bisnis dan Ekonomi Edisi Pertama, Yogyakarta: UPP AMP YPKN.

Mankiw, N. G., Quah, E., \& Wilson, P. (2014). Pengantar Ekonomi Makro Volume 2, Biro Bahasa Alkemis.

Mishkin, F. S. (2008). Ekonomi Uang, Perbankan, dan Pasar Keuangan, Jakarta: Salemba Empat. 
Analysis of the effects of inflation, interest rate, dow jones Islamic Malaysia Index ...

Munawir, S. (2004). Analisis Laporan Keuangan, Yogyakarta: Liberty.

Warno, W., Mujibatun, S., \& Sariroh, L. (2020). Corporate Social Responsibility Disclosure, Capital Intensity, dan Profitabilitas Terhadap Tax Avoidance. JURNAL CAPITAL: Kebijakan Ekonomi, Manajemen dan Akuntansi, 2(1), 39-56.

Nopirin. (1996). Ekonomi Moneter: Edisi 2, Yogyakarta: BPFE-UGM.

Novianto, A. (2011). Analisis Pengaruh Nilai Tukar (Kurs) Dolar Amerika/Rupiah, Tingkat Suku Bunga SBI, Inflasi dan Jumlah Uang Beredar (M2) Terhadap Indeks Harga Saham Gabungan (IHSG) di Bursa Efek Indonesia (BEI) Periode 1999.1-2010.6. Skripsi. Semarang: Universitas Diponegoro.

Persada, G., \& Lawrence J. (2008). Principles of Managerial Finance, Boston: Addison-Wesley.

Prabawa, E. P. (2017). Guncangan Variabel Makroekonomi Terhadap Jakarta Islamic Index (JII), CAKRAWALA: Jurnal Studi Islam, 22(1).

Puspopranoto, S. (2004). Keuangan Perbankan dan Pasar Keuangan, Jakarta: Pustaka LP3ES Indonesia.

Raharjaputra, H. S. (2009). Manajemen Keuangan Dan Akuntansi Untuk Eksekutif Perusahaan Cetakan Pertama, Jakarta: Salemba Empat.

Riyanto. B, (2008). Dasar-Dasar Pembelanjaan Perusahaan, Yogyakarta: GPFE.

Riyani, Y. (2019). Pengaruh Pengumuman Kebijakan Dividen terhadap Volatilitas Harga Saham. Eksos, 15(2), 85-94.

Samuelson, P. A., \& Nordhaus, W. D. (1991). Ekonomi Edisi 12, Jakarta: Erlangga.

Sawir, A. (2009). Analisa Kinerja Keuangan dan Perencanaan Keuangan Perusahaan, Jakarta: Gramedia Pustaka Utama.

Sunariyah, (2013). Pengantar Pengetahuan Pasar Modal, Yogyakarta: UPPSTIM YKPN.

Syamsuddin. (2009). Manajemen Keuangan Perusahaan, Jakarta: Raja Grafindo.

Todaro. M. P. (2000). Pembangunan Ekonomi di Dunia Ketiga, Jakarta: Erlangga. 
Sofyan Halim

Uma, S., \& Roger, B. (2010). Research Methods for Business, a Skill Building Approrach, 5th edition, Wiley Publication.

Yulianah, E. K. (2017). Risiko Pembiayaan Murabahah, Mudharabah dan Musyarakah BUS Terhadap Profitabilitas (ROA) Periode

JIAFR | 294 2011-2015, Jurnal Profita, 10(1). 